Brit. F. vener. Dis. (1971) 47, 122

\title{
Studies on T-strain mycoplasmas in nongonococcal urethritis
}

\author{
E. JANSSON*, A. LASSUS, S. STUBB, AND S. TUURI \\ From the Municipal Bacteriological Laboratory, Aurora Hospital, and the Out-Patient Department for \\ Venereal Diseases, University Central Hospital, Helsinki, Finland
}

Shepard (1954) first isolated T-strain mycoplasmas from patients with nongonococcal urethritis (NGU), but their possible pathogenic role still remains obscure. Some surveys suggest a causal relationship (Shepard, 1960; Shepard, Alexander, Lunceford, and Campbell, 1964; Shepard, 1970; Ford and Du Vernet, 1963; Ford, Rasmussen, and Minken, 1962; Csonka, Williams, and Corse, 1966; Shipley, Bowman, and O'Connor, 1968), while other studies do not support this view (Ingham, MacFarlane, Hale, Selkon, and Codd, 1966; Black and Rasmussen, 1968; Taylor-Robinson, Addey, Hare, and Dunlop, 1969; Fowler and Leeming, 1969). The highest rate of association of $\mathrm{T}$-strain mycoplasmas with human NGU was observed by Shepard (1969) in fourteen (93 per cent.) of fifteen cases. With one exception, they were patients with previously untreated, primary, and recurrent NGU, who had not received treatment for NGU or any other condition with any known drug for 60 days before culture.

There appear to be differences in the carrier rates of T-strain mycoplasmas in the urogenital tract, depending on sexual activity. Archer (1968), who studied the presence of the T-strain mycoplasma in cultures of the urine of 100 pregnant women, 94 women attending an infertility clinic, 98 women in a geriatric unit, and 105 nuns of an enclosed order, found it to be present in $58,51,29$, and 8 per cent. respectively. Women may be primarily asymptomatic carriers of the $\mathrm{T}$-strain mycoplasma in the genitourinary tract (Shepard, 1969).

The aim of the present study was to investigate the presence of $\mathrm{T}$-strain mycoplasmas in male patients with NGU and a possible antibody response against some isolates. The effect of doxycycline treatment upon NGU was also investigated and the results are published separately (Lassus, Perko, Stubb, Mattila, and Jansson, 1971).

^Supported by a grant from the Finnish State Medical Research Council

Received for publication September 28, 1970

\section{Material}

Specimens of urethral discharge were collected from a series of patients (Group I), and specimens from Groups II and III served as controls.

GROUP I 157 male patients treated at the Out-Patient Department for Venereal Diseases, University Central Hospital, Helsinki. Only those with a definite urethral discharge were included in the study. Neisseria gonorrhoeae and Trichomonas vaginalis were excluded by microscopical examination and culture in all cases.

GROUP II 36 sailors without NGU receiving health certificates from the same department.

GROUP III 39 recruits treated for nonvenereal diseases at the First Central Military Hospital, Helsinki.

\section{Collecting the specimens}

The specimens were collected by light intraurethral scraping with a 22-gauge platinum loop inserted 1 to 2 in. into the urethra, with the meatus held open to avoid contact. These were immediately inoculated into mycoplasma broth medium by rotating the loop in the broth tube. The cultures were then put into a $37^{\circ} \mathrm{C}$. incubator without delay. No information was given to the laboratory personnel about the source of specimens, so as to ensure that all were examined objectively. Paired sera were collected from 54 patients with NGU. Single serum specimens were taken from 100 patients and 32 sailors.

\section{Culture}

ISOLATION TECHNIQUE

As culture media, the broth and solid PPLO media described by Marmion (1967) were used, with the following modifications:

(1) Brain heart infusion broth was used instead of PPLO broth; 1.1 per cent. agar was added to it to make a solid medium.

(2) Instead of glucose, $0 \cdot 1$ per cent. urea was added. From the solid medium urea and phenol red were omitted.

(3) Penicillin G and thallium acetate were replaced by ampicillin at a concentration of $50 \mu$ per $\mathrm{ml}$.

(4) The $\mathrm{pH}$ was adjusted to $6 \cdot 5$.

The broth medium was divided into tubes, $2 \mathrm{ml}$. per 
tube, and prepared weekly. For the solid medium, small Petri dishes $5 \mathrm{~cm}$. in diameter were used.

Otherwise, the isolation method was that recommended by Taylor-Robinson, Addey, and Goodwin (1969). In the laboratory, the broth cultures were inspected daily for 10 days; when a colour change to red was observed, $0 \cdot 1$ $\mathrm{ml}$. of the broth culture was inoculated on to solid media. The:e were incubated for 2 days at $37^{\circ} \mathrm{C}$. in an atmosphere of 90 per cent. $(v / v) \mathrm{N}_{2}$ and 10 per cent. $\mathrm{CO}_{2}$.

All agar cultures were stained in situ with drops of 10 per cent. Dienes stain, as suggested by Hers (1965). With this exception, the method followed was that described by Madoff (1960) for the identification of mycoplasmas by the stained agar technique. An agar block of about 1-1.5 cm. ${ }^{2}$ was cut off, mounted on a microscope slide with a cover glass, and examined with 100-fold magnification by Leitz Orthoplan microscope with an Achr. $0.70 / \mathrm{L} 4$ condenser. Suspected colonies were examined with 1,000-fold magnification and an oil immersion lens. The photographs were taken with a Leitz Orthomat camera.

\section{GROWTH INHIBITION TEST}

This was performed by the method of Clyde (1964).
INDIRECT HAEMAGGLUTINATION (IHA) TECHNIQUE
Two T-strain isolates, $71-\mathrm{T}$ and $142-\mathrm{T}$, were used as antigens. They were grown in the mycoplasma broth $\overline{0}$ medium, washed twice with saline, and concentrated $\frac{C}{0}$ 100 -fold. Thereafter they were sonicated for $2 \mathrm{~min}$. in $\overline{\bar{\omega}}$ a model MSE 100 Watt ultrasonic disintegrator. The $\vec{\nabla}$ technique reported earlier by other workers for myco- $\varrho$ plasma antibody studies was used with fresh, tannic acid- ळ treated erythrocytes (Dowdle and Robinson, 1964; $\vec{O}$ Taylor-Robinson, Canchola, Fox, and Chanock, 1964). Bovine albumin (from Sigma Chemical Co.) was added to the dilutant in the ratio of $1: 25$.

\section{Results}

Isolation studies

The frequencies of isolation of the T-strain myco- $\vec{N}$ plasma from urethral specimens are shown in Table $\mathrm{I}_{\mathrm{O}}$ (overleaf).

In Group I, a large colony mycoplasma was obtain- $\vec{\overrightarrow{ }}$ ed with a $\mathrm{T}$-strain mycoplasma in thirty cases (19 per음 cent.); in Groups II and III together they were found in ten cases (13 per cent.). Figs 1 and $2 \overrightarrow{0}$ 
TABLE I Isolation of T-strain mycoplasma from three groups of males

\begin{tabular}{|c|c|c|c|c|}
\hline \multirow{2}{*}{\multicolumn{2}{|c|}{ Group }} & \multirow[t]{2}{*}{$\begin{array}{l}\text { Total no. } \\
\text { examined }\end{array}$} & \multicolumn{2}{|c|}{$\begin{array}{l}T \text {-strain mycoplasma } \\
\text { isolations }\end{array}$} \\
\hline & & & $\begin{array}{l}\text { No. } \\
\text { infected }\end{array}$ & $\begin{array}{l}\text { Percentage } \\
\text { positive }\end{array}$ \\
\hline $\begin{array}{l}\text { I } \\
\text { II } \\
\text { III }\end{array}$ & $\begin{array}{l}\text { Men with NGU } \\
\text { Sailors without NGU } \\
\text { Recruits without NGU }\end{array}$ & $\begin{array}{r}157 \\
36 \\
39\end{array}$ & $\begin{array}{r}90 \\
19 \\
9\end{array}$ & $\begin{array}{l}58 \\
53 \\
23\end{array}$ \\
\hline
\end{tabular}

illustrate the microscopical appearance of two Tstrain isolates.

\section{Growth inhibition studies}

Of forty large colony mycoplasma strains isolated, 26 were identified as $M$. hominis, four as $M$. arthritidis, and two as $M$. fermentans. Five isolates could not be subcultured well enough for identification, and three were contaminated with a yeast.

\section{Antibody studies}

Paired sera from 54 patients with NGU were studied by the IHA technique. Two isolates, 71-T and 142- $\mathrm{T}$, were used as antigens. All sera gave negative results in the first dilution; titre $1: 8$ with the antigen 142-T. The results obtained with the antigen 71-T are shown in Table II. Of the 54 patients examined, thirteen (24 per cent.) revealed a 4-fold or greater rise or fall in the titre, or a titre $\geqslant 1: 64$ in their paired serum specimens.

Only single serum specimens were taken from 100 patients with NGU and from 32 sailors. Table III shows the peak antibody titre against strain 71-T in the cases of all 154 patients and 32 sailors examined. The sailor with the antibody titre $1: 16,384$ had previously had several attacks of NGU, but was symptom-free at the time of the examination.
TABLE II I Peak antibody titre in patients with $N G U$ and in sailors

\begin{tabular}{|c|c|c|}
\hline Titre & No. of patients & No. of sailors \\
\hline $\begin{array}{r}<8 \\
8 \\
16 \\
32 \\
64 \\
128 \\
256 \\
512 \\
1024 \\
2048 \\
4096 \\
8192 \\
16384\end{array}$ & $\begin{array}{r}121 \\
6 \\
3 \\
1 \\
12 \\
2 \\
2 \\
3 \\
2 \\
1 \\
1\end{array}$ & $i$ \\
\hline Total & 154 & 32 \\
\hline
\end{tabular}

\section{Comments}

The incidence of T-strain mycoplasmas in this study agrees with the findings in earlier studies (Ford and DuVernet, 1963; Csonka, and others, 1966; Shipley and others, 1968). The higher carrier rate in patients with NGU than in recruits suggests that human genital mycoplasmas are sexually transmitted, as already concluded by Morton, Smith, and Leberman (1951) and Klieneberger-Nobel (1959). Of much greater interest are the present antibody studies. Earlier, only Ford (1967), using the metabolic inhibition test, was able to show slight antibody rises in two patients out of eleven; the titres observed were $0 \rightarrow 4$ and $0 \rightarrow 16$. By the indirect haemagglutination technique, we found an antibody pattern compatible with a recent $\mathrm{T}$-strain mycoplasma infection in thirteen out of 54 cases. This suggests that, in these patients at least, a T-strain mycoplasma played a pathogenic role. Using another $\mathrm{T}$-strain isolate as antigen, all the sera were negative. This indicates that perhaps only some of the ten known T-strain mycoplasma

TABLE II Isolation of T-strain mycoplasmas and pattern of antibody change in thirteen patients with NGU

\begin{tabular}{|c|c|c|c|c|c|c|c|}
\hline \multirow[t]{2}{*}{ Patient no. } & \multicolumn{4}{|c|}{ Isolation of $T$-strain mycoplasma } & \multicolumn{2}{|c|}{ Pattern of antibody titre } & \multirow{2}{*}{$\begin{array}{l}\text { Days from onset of } \\
\text { disease }\end{array}$} \\
\hline & \multicolumn{2}{|c|}{ 1st Specimen } & \multicolumn{2}{|c|}{ 2nd Specimen } & Acute phase & Convalescent phase & \\
\hline 1 & $6 / 8$ & + & $21 / 8$ & + & $<8$ & 16 & 6 \\
\hline 2 & $25 / 9$ & + & $9 / 10$ & - & 1024 & 512 & 21 \\
\hline $3 *$ & $20 / 10$ & + & $3 / 11$ & - & 32 & 64 & 1 \\
\hline 4 & $22 / 10$ & + & $10 / 11$ & + & 64 & $<8$ & 7 \\
\hline $5^{\star}$ & $21 / 10$ & + & $13 / 11$ & + & $<8$ & 4096 & $>1 \mathrm{mth}$ \\
\hline $6^{\star}$ & $21 ! 11$ & + & $4 / 12$ & + & 64 & $<8$ & 2 \\
\hline 7 & $3 / 11$ & - & $29 / 12$ & - & 128 & 128 & 10 \\
\hline 8 & $29 / 12$ & + & $23 / 1$ & - & 128 & $<8$ & $>1 \mathrm{mth}$ \\
\hline 9 & $2 / 2$ & + & $11 / 2$ & - & $<8$ & 32 & 14 \\
\hline 10 & $17 / 1$ & + & $2 / 2$ & + & $<8$ & 16 & 2 \\
\hline 11 & $18 / 2$ & + & $6 / 3$ & - & 8 & 64 & 6 \\
\hline 12 & $26 / 2$ & + & $17 / 3$ & - & $<8$ & 512 & 11 \\
\hline $13^{\star \star}$ & $28 / 4$ & + & $12 / 5$ & + & $<8$ & 512 & $>1 \mathrm{mth}$ \\
\hline
\end{tabular}


serotypes (Shepard, 1970) may cause disease in man.

Shipley and others (1968) concluded that it was difficult to see how final and definite evidence of the aetiological role of $\mathrm{T}$-strain mycoplasmas in NGU could be obtained by any method other than the inoculation of pure cultures into volunteers, but this procedure may be too risky, because our knowledge of human mycoplasma infections still remains limited.

\section{Summary}

The incidence of T-strain mycoplasmas was studied in 157 male patients with NGU, 36 sailors without $\mathrm{NGU}$, and 39 recruits with nonvenereal diseases; they were demonstrated in 58,53 and 23 per cent. respectively. Of 54 patients with NGU examined, thirteen (24 per cent.) showed an antibody response to one of the two isolates tested which was compatible with a recent infection with $\mathrm{T}$-strain mycoplasma.

\section{References}

ARCHER, J. F. (1968) Brit. F. vener. Dis., 44, 232

BlaCK, F. T., and RASMuSSEN, O. G. (1968) Ibid., 44, 324 Clyde, W. A. (1964) F. Immunol., 92, 958

CsonkA, G. W., Williams, R. E. O., and Corse, J. (1966) Lancet, 1, 1292

Dowdle, W. R., and Robinson, R. Q. (1964) Proc. Soc. exp. Biol. (N.Y.), 116, 947

Ford, D. K. (1967) Ann. N.Y. Acad. Sci., 143, 501

- and DU Vernet, M. (1963) Brit. F. vener. Dis., 39, 18

- Rasmussen, G., and Minken, J. (1962) Ibid., 38, 22

FowLER, W., and LEEMING, R. J. (1969) Ibid., 45, 287

HeRs, J. P. (1965) Personal communication

Ingham, H. R., MacFarlane, W. V., Hale, J. H., Selkon, J. B., and CodD, A. A. (1966) Brit. F. vener. Dis., 42, 269

Klieneberger-Nobel, E. (1959) Brit. med. F., 1, 19
Lassus, A., Perko, R. L., Stubb, S., Mattila, R., and Jansson, E. (1971) Brit. F. vener. Dis., 47, 126

Madoff, Sarabelle (1960) Ann. N.Y. Acad. Sci., 79, 383

MARMION, B. P. (1967) In 'Recent Advances in Medical Microbiology, ed. A. P. Waterson, p. 170, Churchill, London

Morton, H. E., Smith, P. F., and Leberman, P. R. (1951) Amer. F. Syph., 35, 14

ShePARD, M. C. (1954) Amer. F. Syph., 38, 113

- (1960) Ann. N.Y. Acad. Sci., 79, 397

(1969) In 'The Mycoplasmatales and the L-phase of Bacteria', ed. L. Hayflick, p. 47. North-Holland Publishing Co., Amsterdam

(1970) F. Amer. med. Ass., 211, 1335

- Alexander, C. E., LunCeford, C. D., and CAMPBELL, P. E. (1964) Ibid., 188, 729

Shipley, A., Bowman, S. J., and O'Connor, J. Jean (1968) Med. F. Aust., 1, 794

TAYLOR-Robinson, D., AdDEY, J. P., and Goodwin, C. S. (1969) Nature (Lond.), 222, 274

- - HARE, M. J., and Dunlop, E. M. C. (1969) Brit. F. vener. Dis., 45, 265

- Canchola, J., Fox, H., and Chanock, R. M. (1964) Amer. F. Hyg., 80, 135

Étude sur les mycoplasmes, souche $T$, dans l'urétrite non gonococcique

\section{SOMMAIRE}

L'incidence des mycoplasmes de souche $\mathrm{T}$ fut étudiée chez 157 hommes atteints d'urétrite non gonococcique (UNG), 36 marins sans UNG et 39 recrues présentant diverses maladies non vénériennes. Ces mycoplasmes furent trouvés, respectivement, dans 58,53 et 23 pour cent des cas. Chez 54 malades atteints d'UNG, 13 (24 pour cent) donnèrent une réponse immunologique positive vis-à-vis de l'une des deux souches isolées, ce qui est compatible avec une infection récente par mycoplasme souche $T$. 